\author{
ANDRZEJ GALBARCZYK \\ Zakład Zdrowia i Środowiska \\ Wydziat Nauk o Zdrowiu \\ Uniwersytet Jagielloński Collegium Medicum \\ Grzegórzecka 20, 31-531 Kraków \\ E-mail: agalbarczyk@gmail.com
}

\title{
SYN CÓRCE NIERÓWNY, CZYLI O WPŁYWIE PŁCI URODZONYCH DZIECI NA FIZJOLOGIE I ZDROWIE MATKI
}

Szeroko rozumiana reprodukcja, czyli bycie w ciąży, urodzenie i wychowanie dzieci, nie jest obojętna dla organizmu matki. Część zmian zachodzących w organizmie jest dobrze poznana i ma bezpośredni zwiazek $z$ byciem w ciąży i karmieniem piersia, inne zaś zmiany moga być obserwowane dopiero w późniejszym wieku. Co więcej, dla organizmu kobiety nie jest obojętne, czy rodzi córkę czy syna, a przykłady tego, że synowie i córki inaczej wpływaja na fizjologię matki, obserwowane sa już na etapie ciąży.

\section{CIĄŻA}

Ciąża stanowi duży wydatek energetyczny dla organizmu matki. Podstawowa przemiana materii kobiet ciężarnych jest zwiększona, gdyż dodatkowa energia musi być przeznaczana na rozwój płodu, łożyska, rozrost macicy i gruczołów mlecznych. Badania pokazuja, że bycie w ciąży $z$ chłopcem jest dla matki dużo większym obciażeniem niż bycie w ciąży $z$ dziewczynka. Synowie sa więksi już na etapie zarodka (PERGAMENt i współaut. 1994) oraz szybciej rozwijaja się podczas życia płodowego (MARSÁL i współaut. 1996), co w konsekwencji prowadzi do tego, że chłopcy rodzą się więksi od dziewczynek (DE ZEGHER i współaut. 1999). Chłopcy rodzą się więksi zarówno $z$ ciąż pojedynczych (Cogswell i YIP 1995), jak i ciąż bliźniaczych (LI i współaut. 2015). Co więcej, w przypadku ciaż bliźniaczych chłopcy, których bliźniakiem była siostra, rodza się więksi od chłopców, których bliźniakiem był drugi chłopiec (JELENKOVIC i współaut. 2018).
Zwiększone zapotrzebowanie na energię zwiazane $z$ byciem $w$ ciąży $z$ synem przekłada się na większe spożycie kalorii. Kobiety będące $\mathrm{w}$ ciąży $\mathrm{z}$ chłopcem spożywają o $10 \%$ więcej kalorii niż kobiety będące w ciąży z dziewczynka (TAMIMI i współaut. 2003). Kolejnym dowodem wskazujacym na to, że urodzenie syna jest dla matki większym obciażeniem niż urodzenie córki może być fakt, że po urodzeniu syna kobieta później rodzi kolejne dziecko (MACE i SEAR 1997). Dłuższy okres pomiędzy dwiema ciążami może sugerować, iż organizm matki potrzebuje dłuższej regeneracji przed kolejnym zajściem w ciażę.

Oprócz wyższych kosztów metabolicznych, kobiety będace $\mathrm{w}$ ciąży $\mathrm{z}$ synami narażone sa również na bardziej znaczące zmiany $\mathrm{w}$ funkcjonowaniu układu immunologicznego. Błony komórkowe męskiego płodu zawieraja antygeny $\mathrm{H}-\mathrm{Y}$ należące do antygenów zgodności tkankowej Y. Matki chłopców rozwijaja odpowiedź immunologiczna przeciwko antygenom $\mathrm{H}-\mathrm{Y}$, a przeciwciała anty $\mathrm{H}-\mathrm{Y}$ wykrywane sa w krwi matki nawet 22 lata po urodzeniu chłopca (VERDIJK i współaut. 2004). Sugeruje się, że ta odpowiedź immunologiczna matki może prowadzić do częstszych poronień kolejnych ciąż po urodzeniu syna (NIELSEN i współaut. 2008). Wykazano również, że chłopcy urodzeni po starszym bracie rodzili się mniejsi, w porównaniu do chłopców urodzonych po starszej siostrze (BLANCHARD i ELLIS 2001, Côté i współaut. 2003). Jednak inne badania wykazały, że starsi bracia negatywnie wpływają na wielkość urodzeniową młodsze- 
go rodzeństwa niezależnie od jego płci (NIELSEN i współaut. 2008).

Bycie w ciąży $z$ chłopcem wiąże się też z częstszym pojawianiem się niektórych powikłań, takich jak: cukrzyca ciążowa, nadciśnienie tętnicze i makrosomia płodu (SHEINER i współaut. 2004, VERBURG i współaut. 2016). Chłopcy częściej rodzą się jako wcześniaki, a kobiety będące $w$ ciąży $z$ synem częściej przechodzą cesarskie cięcie lub poród wspomagany (AIBAR i współaut. 2012).

Kolejnym przykładem różnic zachodzących w ciele kobiety podczas ciaży w zależności od płci dziecka, sa zmiany w rozmiarze piersi. Wykazano, że kobiety, które urodziły dziewczynkę, doświadczyły w trakcie cią̇y większej zmiany w rozmiarze piersi niż kobiety, które urodziły chłopca (GALBARCZYK 2011). Wyniki te zadaja poniekąd kłam madrości ludowej twierdzącej, że w ciaży dziewczynki „kradna matce urodę.”

Nie jest jednak tak, że bycie w ciąży z córka jest korzystniejsze dla matki pod każdym względem. U takich kobiet częściej występują nudności i wymioty (NAUMANN i współaut. 2012). Może być to zwiazane $Z$ tym, że w krwi kobiet będących w ciąży $z$ córka obserwuje się większe stężenia $\beta$-hCG (gonadotropiny kosmówkowej podtyp $\beta$ ), hormonu produkowanego w kosmówce łożyska (YARON 2002). Podwyższone stężenia tego hormonu sprzyjaja występowaniu nudności i wymiotów w trakcie ciąży (FURNEAUX i współaut. 2001).

Cią̇a zmienia też $\mathrm{w}$ pewnym stopniu funkcjonowanie mózgu kobiety (HoEKzEMA i współaut. 2017). Bycie w ciąży z synem wydaje się korzystniejsze dla funkcji poznawczych matki. Funkcje poznawcze to czynności psychiczne zwiazane m.in. $z$ orientacja $w$ przestrzeni, zapamiętywaniem i analizowaniem informacji, wyciaganiem wniosków czy podejmowaniem decyzji. Wykazano, że kobiety będące w ciąży $z$ chłopcami lepiej radza sobie $z$ rozwiazywaniem najtrudniejszych zadań zwiazanych z zapamiętywaniem, służacych do oceny funkcji poznawczych (VANSTON i WATSON 2005). Autorzy tego badania wskazuja, że gonadotropina kosmówkowa przenika przez barierę krew-mózg i wpływa na wiele struktur w mózgu, w tym na hipokamp i korę mózgowa (LEI i RAO 2001). Zatem wyższe stężenia tego hormonu u kobiet będacych $\mathrm{w}$ ciąży $\mathrm{z}$ córkami moga prowadzić do większych zmian w funkcjonowaniu mózgu i bardziej ograniczać funkcje poznawcze matki.

\section{PO PORODZIE}

Różnice w konsekwencjach urodzenia syna lub córki nie kończą się na okresie ciąży. Istnieja badania sugerujace, że kobiety, które urodziły córkę częściej doświadczaja depresji poporodowej $\mathrm{w}$ porównaniu $\mathrm{z}$ kobietami, które urodziły syna. Należy jednak zaznaczyć, że wyniki te pochodzą z krajów, gdzie posiadanie syna jest kulturowo dużo bardziej pożądane, przykładowo $z$ Indii (JAIN i współaut. 2014, GOYAL i współaut. 2017), z Iranu (KHEIRABADI i współaut. 2009) czy z Nigerii (ADEwUYA i współaut. 2005). Można zatem założyć, że częstsza depresja poporodowa po urodzeniu córki w tych społecznościach jest wynikiem niespełnionych, kulturowo uwarunkowanych oczekiwań, a nie fizjologicznych różnic pomiędzy urodzeniem córki i syna. Badania $z$ Indii wykazały również, że kobiety rodzace córki rzadziej podejmuja się karmienia piersia (JAIN i współaut. 2014) lub karmią piersią dużo krócej (JAYACHANDRAN i KUZIEMKO 2011) niż kobiety rodzące synów. Autorzy tych badań sugeruja, że kobiety, które urodziły mniej pożądane kulturowo córki, rezygnują $z$ karmienia piersią, aby szybciej odzyskać możliwość urodzenia kolejnego dziecka - potencjalnie syna.

$\mathrm{O}$ ile specyficznymi uwarunkowaniami kulturowymi można wytłumaczyć zachowania zwiazane $z$ karmieniem niemowlat, $o$ tyle nie można tego zrobić, odnoszac się do różnic w składzie mleka, które matki produkują dla synów i dla córek. Badania sugeruja, że, podobnie jak w przypadku ciąży, produkcja mleka dla chłopców wymaga większych nakładów energetycznych. Badanie przeprowadzone w Stanach Zjednoczonych (Powe i współaut. 2010) wykazało, że kobiety, które urodziły syna, produkuja o $25 \%$ bardziej kaloryczne mleko. Co więcej, badanie przeprowadzone w Chinach (THAKKAR i współaut. 2013) dowodzi, że dla synów matki produkuja nie tylko bardziej kaloryczne, ale i wartościowsze mleko zawierające więcej tłuszczów, wielonienasyconych kwasów tłuszczowych, fosfolipidów i gangliozydów. Natomiast w badaniu przeprowadzonym na Filipinach nie wykazano istotnych różnic pomiędzy mlekiem produkowanym dla córek i synów pod względem zawartości tłuszczów, białek, cukrów i wartości energetycznej (QuiNN 2013), ale stwierdzono, że kobiety karmiące synów spożywaja dziennie dużo więcej kalorii niż matki karmiące córki (odpowiednio 1545 i 1268 kcal). Może to sugerować, że karmienie piersia syna jest jednak większym obciążeniem energetycznym dla matki.

Co więcej, stwierdzono, że kobiety sa zdolne do dostosowania swoich inwestycji zwiazanych $z$ karmieniem piersia do specyficznych uwarunkowań ekologicznych, w których się znajdują. Hipoteza Triversa-Willarda (TRIVERS i WILLARD 1973) zakłada, że 
zważywszy na to, że urodzenie i wychowanie męskiego potomka wymaga więcej energii, tylko kobiety będące w dobrej kondycji i mające dostęp do zasobów powinny zwiększać swoje nakłady ponoszone na wychowanie syna. Zatem kobiety będace w gorszej kondycji energetycznej powinny obrać inną strategię i raczej inwestować swoje zasoby, $\mathrm{w}$ tym energetyczne, w córki. Badanie $z \mathrm{Ke}-$ nii wykazało, że matki o najniższym statusie ekonomicznym produkowały bardziej wartościowe mleko dla córek, $z$ kolei matki w lepszej sytuacji finansowej produkowały bardziej wartościowe mleko dla synów (FUJITA i współaut. 2012).

Istnieje zatem coraz więcej dowodów na to, że płeć urodzonego dziecka może wpływać na fizjologię matki również po porodzie, determinując choćby proces laktacji. Co więcej, odpowiednie dostosowanie produkowanego mleka do płci karmionego dziecka może mieć kluczowe znaczenie dla jego prawidłowego rozwoju. Badanie przeprowadzone na dużej próbie bliźniąt wykazało, że w porównaniu do bliźniąt jednopłciowych, bliźnięta dwupłciowe były o około $2 \mathrm{~cm}$ niższe i ważyły o około $6 \mathrm{~kg}$ mniej jako nastolatkowie, ale jedynie wtedy, kiedy były karmione piersią. Różnic w rozwoju nie zaobserwowano pomiędzy bliźniętami jednopłciowymi i dwupłciowymi nigdy nie karmionymi piersia (KANAZAWA i SEGAL 2017). Można zatem wnioskować, iż produkowane przez matkę mleko może i powinno być dostosowane do płci karmionego dziecka.

\section{W PÓŹNIEJSZYM WIEKU}

Urodzenie córki wpływa na fizjologię matek w inny sposób niż urodzenie syna. Niektóre $z$ tych różnic moga być jednak obserwowane dopiero w późniejszych latach życia matki, wiele lat po urodzeniu i wychowaniu dzieci. Jednym $z$ takich przykładów jest wpływ wieku urodzenia pierwszej córki na wiek, w którym matka przechodzi menopauzę. Jedno $z$ badań wykazało, że im wcześniej kobieta urodziła pierwsza córkę, tym wcześniej przeszła menopauze (GALBARCZYK i JASIENSKA 2013). Zależność ta jest zgodna $z$ tzw. "hipoteza babci”, jedna $z$ hipotez tłumaczacych występowanie menopauzy u ludzi.

Menopauza polega na zaniku występowania cykli menstruacyjnych u kobiet, co w konsekwencji powoduje całkowite zakończenie reprodukcji. Wiele wskazuje na to, że człowiek jest jedynym gatunkiem, u którego samice traca zdolność reprodukcji na długo przed końcem życia (EMERY THOMPSON i współaut. 2007). Jednym $z$ możliwych wytłumaczeń tego fenomenu jest to, że u człowieka dzieci wymagaja wieloletniej opieki ze strony matki, zanim stana się samodzielne. Zatem kobiety musza urodzić swoje ostatnie dziecko odpowiednio wcześniej, aby móc zapewnić mu stosowna opieke i przetrwanie. „Hipoteza babci” opiera się także na założeniu, że wraz $z$ wiekiem matki wzrasta ryzyko zgonu podczas porodu lub ryzyko urodzenia chorego dziecka, zatem w pewnym wieku bardziej korzystne jest zrezygnowanie $z$ własnej reprodukcji i wspieranie reprodukcji córek, tak by maksymalizować ich (a pośrednio swój własny) sukces reprodukcyjny (Hill i HURTADO 1991). Badania wskazuja na to, że rzeczywiście pomoc babki od strony matki pozytywnie wplywa na przeżycie dzieci córek, jednak jedynie wtedy, kiedy babcia sama nie rodzi już dzieci (SEAR i MACE 2008). Ponadto, jedynie w przypadku dzieci urodzonych przez córki, starsza kobieta może mieć całkowita pewność pokrewieństwa $z$ wnukami. To wszystko może tłumaczyć, dlaczego właśnie wcześniejsze posiadanie córki może wpływać na wcześniejszy wiek menopauzy u kobiet.

Inne badania pokazuja, że w późniejszym wieku kobiety ponosza zdrowotne konsekwencje intensywnej reprodukcji (JASIENSKA 2009), bo urodzenie dużej liczby dzieci może odbijać się negatywnie na zdrowiu matki. Wykazano, że kobiety, które urodziły dużo dzieci, w starszym wieku narażone są na wyższy stres oksydacyjny (ZIOMKIEWICZ i współaut. 2016), częściej choruja na choroby układu sercowo-naczyniowego (MAGNuS i współaut. 2017) czy cukrzyce (MUELLER i współaut. 2013), częściej mają problem $z$ uzębieniem (CHRISTENSEN i współaut. 1998) oraz oceniane sa na fotografiach jako starsze i bardziej schorowane (MARCINKOWSKA i współaut. 2017). Wykazano również, że urodzenie dużej liczby dzieci może skutkować krótszym życiem kobiet (GAGNON i współaut. 2009).

Powyższe wyniki zwiazane sa $z$ tak zwanymi kosztami reprodukcji, czyli zasobami, które kobieta przeznacza na urodzenie i wychowanie dzieci kosztem swojego organizmu (KIRKWOOd i Rose 1991, JASIENSKA 2009). Należy zwrócić jednak uwagę, że wyniki te odnosza się do badań, w których analizowano jedynie wpływ całkowitej liczby dzieci na zdrowie matek w późniejszym wieku, jakkolwiek wiadomo, że urodzenie syna zwiazane jest $z$ większymi kosztami ciaży i karmienia piersia.

Badanie przeprowadzone w Polsce sugeruje, że samoocena stanu zdrowia matki w późniejszym wieku zależy od liczby urodzonych synów, ale nie liczby urodzonych córek (GALBARCZYK i współaut. 2018). Każdy urodzony syn zwiększał o $11 \%$ szansę, że matka gorzej oceniała stan swojego zdrowia. 
Warto przy tym zaznaczyć, że samoocena stanu zdrowia, pomimo tego, że jest prostym wskaźnikiem ogólnego stanu zdrowia, ma bardzo duże właściwości predykcyjne. W późniejszym wieku zła samoocena stanu zdrowia koreluje ze zwiększonym ryzykiem zgonu, niezależnie od innych czynników ryzyka takich jak styl życia, czynniki psychospołeczne czy medyczne (IDLER i BENYAMINI 1997). Inne badanie wykazało, że liczba urodzonych synów (ale nie liczba córek) negatywnie wpływa na procesy immunostarzenia się kobiet (MARTTILA i współaut. 2015), czyli występowania przewlekłego stanu zapalnego o niewielkim nasileniu, który może prowadzić do zwiększonego ryzyka wielu chorób (JABŁOŃSKA 2013).

Dwa badania analizujace historyczne dane ze społeczności przedindustrialnych $z$ Finlandii wykazały, że urodzenie dużej liczby synów, ale nie córek, negatywnie wpływało na długość życia matek (HELle i współaut. 2002, Helle i LummaA 2013). Badanie historycznej społeczności Flandrii wykazało, że synowie wpływali negatywnie na długość życia matek jedynie wśród najbiedniejszych kobiet, co może sugerować, że lepiej sytuowane mogły rekompensować wydatki energetyczne związane $z$ rodzeniem synów (VAN DE PUTTE i współaut. 2004).

Można zatem wnioskować, że urodzenie syna wiąze się $z$ wyższymi kosztami dla matki, jednak część tych kosztów może się pojawić dopiero w późniejszym wieku. Posiadanie dużej liczby synów może być dla kobiety bardziej niekorzystne niż urodzenie dużej liczby córek. Jakkolwiek w przypadku nowotworu jajnika, to posiadanie samych córek zwiększa ryzyko wystapienia tej choroby. U kobiet, które urodziły samych synów lub miały zarówno synów, jak i córki, wykazano mniejsze ryzyko zachorowania (GIERACH i współaut. 2006).

\section{WNIOSKI}

Przytoczone badania nie pozwalaja jednoznacznie stwierdzić, co jest korzystniejsze dla matki - rodzenie synów czy córek. W trakcie ciąży, karmienia piersia, jak i wiele lat po zakończeniu reprodukcji, synowie, w porównaniu do córek, wydają się dużo większym obciążeniem metabolicznym i immunologicznym dla organizmu matki. Zatem kobiety będace $w$ ciąży $z$ synami powinny być objęte szczególna opieka, tak samo jak starsze kobiety, które urodziły dużą liczbę synów. Należy jednak pamiętać o tym, że urodzenie córki również może się wiazać $z$ negatywnymi konsekwencjami dla zdrowia matki.
Bezsporne jest jednak to, że aby w pełni zrozumieć konsekwencje reprodukcji dla kobiecego organizmu, niezbędne jest uwzględnianie płci urodzonych dzieci. Podczas badań wszelkich zmian zachodzących w ciele kobiety w trakcie ciaży czy karmienia piersią, jak również badając długofalowe konsekwencje reprodukcji, konieczne jest uwzględnianie płci urodzonych dzieci.

$$
\text { Streszczenie }
$$

Urodzenie syna, w porównaniu do urodzenia córki, w odmienny sposób wpływa na zdrowie i fizjologię matki. W trakcie ciąży synowie są większym obciążeniem energetycznym i immunologicznym dla organizmu kobiety. Matki będące w ciąży $z$ chłopcami częściej choruja na cukrzycę i nadciśnienie ciążowe oraz częściej poddawane są cesarskiemu cięciu. Kobiety będące w ciąży $z$ córkami częściej cierpia na nudności, wymioty i większe zaburzenia funkcji poznawczych. Dla synów matki produkują bardziej wartościowe mleko. Niektóre różnice w konsekwencjach urodzenia synów lub córek obserwowane są dopiero w późniejszym wieku. Urodzenie dużej liczby synów może negatywnie odbijać się na ogólnym zdrowiu matek w późniejszym wieku, co może w konsekwencji zwiększać ryzyko zgonu. Natomiast urodzenie samych córek zwiększa ryzyko wystapienia nowotworu jajnika. Nie jest możliwe jednoznaczne rozstrzygnięcie, czy rodzenie córek jest dla matek bardziej korzystne od rodzenia synów. Jednak aby w pełni zrozumieć konsekwencje reprodukcji dla zdrowia i fizjologii kobiet, niezbędne jest uwzględnianie płci urodzonych dzieci.

\section{LITERATURA}

Adewuya A. O., Fatoye F. O., Ola B. A., IJaodoLA O. R., IBIGBAMI S. M. O., 2005. Sociodemographic and obstetric risk factors for postpartum depressive symptoms in Nigerian women. J. Psychiatr. Pract. 11, 353-358.

Aibar L., Puertas A., Valverde M., Carrillo M. P., Montoya F., 2012. Fetal sex and perinatal outcomes. J. Perinat. Med. 40, 271-276.

BLANCHARD R., ElLIS L., 2001. Birth weight, sexual orientation and the sex of preceding siblings. J. Biosoc. Sci. 33, 451-467.

Christensen K., Gaist D., Jeune B., Vaupel J. W., 1998. A tooth per child? Lancet 352, 204.

COGSWELl M. E., YIP R., 1995. The influence of fetal and maternal factors on the distribution of birthweight. Semin. Perinatol. 19, 222-240.

CÔTÉ K., Blanchard R., LALUMiÈRE M. L., 2003. The influence of birth order on birth weight: Does the sex of preceding siblings matter? J. Biosoc. Sci. 35, 455-462.

De Zegher F., Devlieger H., Eeckels R., 1999. Fetal growth: Boys before girls. Horm. Res. $51,258-259$.

EMERY THOMPSON M., Jones J.H., Pusey A. E., BREWER-MARSDEN S., GoOdAll J., MARSDEN D., Matsuzawa T., Nishida T., Reynolds V., SugiYama Y., WRANGHAM R. W., 2007. Aging and fertility patterns in wild chimpanzees provide insights into the evolution of menopause. Curr. Biol. 17, 2150-2156.

Fujita M., Roth E., Lo Y. J., HuRst C., Vollner J., KENDELL A., 2012. In poor families, mothers' milk is richer for daughters than sons: A test of Trivers-Willard hypothesis in agropastoral settlements in Northern Kenya. Am. J. Phys. Anthropol. 149, 52-59. 
Furneaux E. C., LANGLey-Evans A. J., LANGLEY-EVANS S. C., 2001. Nausea and vomiting of pregnancy: endocrine basis and contribution to pregnancy outcome. Obstet. Gynecol. Surv. $56,775-782$.

Gagnon A., Smith K. R., TRemblay M., VÉzina H., PARÉ P. P., DESJARDINS B., 2009. Is there a trade-off between fertility and longetivity? A comparative study of women from three large historical databases accounting for mortality selection. Am. J. Hum. Biol. 21, 533-540.

GALBARCZYK A., 2011. Unexpected changes in maternal breast size during pregnancy in relation to infant sex: An evolutionary interpretation. Am. J. Hum. Biol. 23, 560-562.

GalbarCZYK A., JASIENSKA G., 2013. Timing of natural menopause covaries with timing of birth of a first daughter: Evidence for a mother-daughter evolutionary contract? HOMO J. Comp. Hum. Biol. 64, 228-232.

GAlbarCZYK A., KLIMEK M., NENKO I., JASIENSKA G., 2018. Sons may be bad for maternal health at older age. New evidence for costs of reproduction in humans. J. Gerontol. Ser. A, doi:10.1093/gerona/gly190.

Gierach G. L., Modugno F., Ness R. B., 2006. Gender of offspring and maternal ovarian cancer risk. Gynecol. Oncol. 101, 476-480.

Goyal K., Purbiya P., Lal S. N., KaUR J., ANTHWA P., PUlIYe J. M., 2017. Correlation of infant gender with postpartum maternal and paternal depression and exclusive breastfeeding rates. Breastfeed. Med. 12, 279-282.

Helle S., LummaA V., 2013. A trade-off between having many sons and shorter maternal post-reproductive survival in pre-industrial Finland. Biol. Lett. 9, 20130034.

Helle S., LummaA V., Jokela J., 2002. Sons reduced maternal longevity in preindustrial humans. Science 296, 1085.

Hill K., HuRTADO A. M., 1991. The evolution of premature reproductive senescence and menopause in human females - An evaluation of the "grandmother hypothesis." Hum. Nat. 2, 313-350.

Hoekzema E., BARBA-MÜller E., Pozzobon C., PicADO M., Lucco F., García-García D., SoliVA J. C., TOBeña A., Desco M., CRONe E. A., Ballesteros A., CARMona S., Vilarroya O., 2017. Pregnancy leads to long-lasting changes in human brain structure. Nat. Neurosci. 20, 287.

IDLER E. L., BENYAMINI Y., 1997. Self-rated health and mortality: a review of twenty-seven community studies. J. Health Soc. Behav. 38, 21 37.

JABŁONSKA M. K., 2013. Immunostarzenie-wpływ procesu starzenia na komponenty układu immunologicznego. Gerontol. Pol. 4, 143-147.

Jain A., Tyagi P., KauR P., PuliYel J., SREenIVAS V., 2014. Association of birth of girls with postnatal depression and exclusive breastfeeding: an observational study. BMJ Open 4, $\mathrm{e} 003545$.

JASIENSKA G., 2009. Reproduction and lifespan: Tradeoffs, overall energy budgets, intergenerational costs, and costs neglected by research. Am. J. Hum. Biol. 21, 524-532.

JAYACHANDRAN S., KUZIEMKO I., 2011. Why do mothers breastfeed girls less than boys? Evidence and Implications for Child Health in India. Q. J. Econ. 126, 1485-1538.

JELENKOVIC A., SUND R., YOKOYAMA Y., HuR Y. M., Ullemar V., AlmQVist C., MAGNUSSON P. K., WilleMSEN G., BARTELS M. i współaut., 2018. Birth size and gestational age in opposite-sex twins as compared to same-sex twins: An individual-based pooled analysis of 21 cohorts. Sci. Rep. 8, 6300.

Kanazawa S., Segal N. L., 2017. Same-sex twins are taller and heavier than opposite-sex twins (but only if breastfed): Possible evidence for sex bias in human breast milk. J. Exp. Child Psychol. 156, 186-191.

KHEIRABADI G.-R., MARACY M.-R., BAREKATAIN M., SAleHI M., SAdRI G.-H., Kelishadi M., CASSY P., 2009. Risk factors of postpartum depression in rural areas of Isfahan Province, Iran. Arch. Iran. Med. 12, 461-467.

KIRKWOOD T. B. L., ROSE M. R., 1991. Evolution of senescence: late survival sacrificed for reproduction. Philos. Trans. R. Soc. London, B 332, 15-24.

LEI Z. M., RAO C. V., 2001. Neural Actions of Luteinizing Hormone and Human Chorionic Gonadotropin. Semin. Reprod. Med. 1, 5844662.

Li Z., Umstad M. P., Hilder L., Xu F., Sullivan E. A., 2015. Australian national birthweight percentiles by sex and gestational age for twins, 2001-2010. BMC Pediatr. 15, 148.

MACE R., SEAR R., 1997. Birth interval and the sex of children in a traditional African population: An evolutionary analysis. J. Biosoc. Sci. 29, 499-507.

Magnus M. C., Iliodromiti S., LAWlor D. A., CATOV J. M., NELSON S. M., FRASER A., 2017. Number of offspring and cardiovascular disease risk in men and women: the role of shared lifestyle characteristics. Epidemiology $28,880-888$.

MarcinkowsKa U. M., LitTle A. C., GalbarczyK A., Nenko I., KlimeK M., JasiensKA G., 2017. Costs of reproduction are reflected in women's faces: Post-menopausal women with fewer children are perceived as more attractive, healthier and younger than women with more children. Am. J. Phys. Anthropol. 165, 589593.

MARSÁL K., PERSSON P. H., LARSEN T., LILJA H., SELBING A., SUlTAN B., 1996. Intrauterine growth curves based on ultrasonically estimated foetal weights. Acta Paediatr. 85, 843-848.

MARTTILA S., NEVAlainen T., KANANEN L., JYLHÄVÄ J., JYLHÄ M., HERVONEN A., ILONEN J., HURME M., 2015. Number of sons contributes to ageing-associated inflammation. Sci. Rep. $5,8631$.

Mueller N. T., Mueller N. J., OdegaArd A. O., GROSS M. D., KOH W. P., YUAN J. M., PEREIRA M. A., 2013. Higher parity is associated with an increased risk of type-II diabetes in Chinese women: the Singapore Chinese Health Study. BJOG An Int. J. Obstet. Gynaecol. 120, 1483-1489.

NaumanN C. R., Zelig C., Napolitano P. G., Ko C. W., 2012. Nausea, vomiting, and heartburn in pregnancy: A prospective look at risk, treatment, and outcome. J. Matern. Neonatal Med. $25,1488-1493$.

Nielsen H. S., MORTENSEN L., NyGaARD U., SCHNOR O., CHRISTIANSEN O. B., ANDERSEN A.' M. N., 2008. Brothers and reduction of the birth weight of later-born siblings. Am. J. Epidemiol. 167, 480-484.

Pergament E., Fiddler M., Cho N., Johnson D., HOLMGREN W. J., 1994. Fertilization and early embryology: Sexual differentiation and preimplantation cell growth. Hum. Reprod. 9, 17301732. 
Powe C. E., KnotT C. D., ConkLin-BritTAin N., 2010. Infant sex predicts breast milk energy content. Am. J. Hum. Biol. 22, 50-54.

QUINN E. A., 2013. No evidence for sex biases in milk macronutrients, energy, or breastfeeding frequency in a sample of Filipino mothers. Am. J. Phys. Anthropol. 152, 209-216.

SEAR R., MACE R., 2008. Who keeps children alive? A review of the effects of kin on child survival. Evol. Hum. Behav. 29, 1-18.

SHEINER E., LEVY A., KATZ M., HERSHKOVITZ R., LERON E., MAZOR M., 2004. Gender does matter in perinatal medicine. Fetal Diagn. Ther. 19, 366-369.

Tamimi R. M., Lagiou P., Mucci L. A., Hsieh C.C., AdAmi H.-O., TRIChOPOUlos D., 2003. Average energy intake among pregnant women carrying a boy compared with a girl. BMJ 326, 1245-1246.

THAKKAR S. K., GiUfFrida F., CRistina C. H., De Castro C. A., MukherJee R., Tran L. A., Steenhout P., LeE L. Y., Destaillats F., 2013. Dynamics of human milk nutrient composition of women from singapore with a special focus on lipids. Am. J. Hum. Biol. 25, 770-779.

TRIVERS R. L., WILlaRD D. E., 1973. Natural selection of parental ability to vary the sex ratio of offspring. Science 179, 90-92.

Van DE PUTTe B., MatThiJs K., Vlietinck R. 2004. A social component in the negative ef- fect of sons on maternal longevity in pre-industrial humans. J. Biosoc. Sci. 36, 289-297.

VANSTON C. M., WATSON N. V., 2005. Selective and persistent effect of foetal sex on cognition in pregnant women. Neuroreport. 16, 779782.

VERBURG P. E., TUCKeR G., ScheIL W., JAAP J., ERWich H. M., DeKKer G. A., Roberts C. T., 2016. Sexual dimorphism in adverse pregnancy outcomes - a retrospective Australian population study 1981-2011. PLoS One 11, e0158807.

VerdiJK R. M., Kloosterman A., Pool J., Van De Keur M., Naipal A. M. I. H., Van Halteren A. G. S., BRAND A., Mutis T., Goulmy E., 2004. Pregnancy induces minor histocompatibility antigen-specific cytotoxic T cells: Implications for stem cell transplantation and immunotherapy. Blood 103, 1961-1964.

YARON Y., 2002. Maternal serum HCG is higher in the presence of a female fetus as early as week 3 post-fertilization. Hum. Reprod. 17, 485-489.

Ziomkiewicz A., Sancilio A., GalbarczyK A., KLIMEK M., JASIENSKA G., BRIBIESCAS R. G., 2016. Evidence for the cost of reproduction in humans: High lifetime reproductive effort is associated with greater oxidative stress in post-menopausal women. PLoS One 11, e0145753.

KOSMOS Vol. 68, 1, 13-18, 2019

\section{ANDRZEJ GALBARCZYK}

Department of Environmental Health, Faculty of Health Sciences, Jagiellonian University Medical College, Grzegórzecka 20, 31-531 Kraków, E-mail: agalbarczyk@gmail.com

\section{SON OR DAUGHTER? DIFFRENT IMPACT OF CHILD SEX ON MATERNAL PHYSIOLOGY AND HEALTH}

\section{Summary}

Child-bearing influences maternal physiology and health in a sex-dependent way. Sons are more demanding energetically and have a more negative impact on the maternal immune system during pregnancy. Pregnancies with male fetuses are associated with a higher risk of gestational diabetes and caesarian section. Women carrying a female fetus are more prone to nausea, vomiting and reduced cognitive performance. Mothers of sons produce more nutritious milk. Some of the differences in consequences between having a son or a daughter can be detected in the later life. A high number of born sons may be associated with worst maternal self-rated health and shorter lifespan. But giving birth solely to girls may appear to be associated with an increased risk in maternal ovarian cancer. It is not clear, however, whether having daughters is more beneficial for woman than having sons. In order to understand the consequences of reproduction, the sex of children should be taken into account.

Key words: cost of reproduction, evolutionary medicine, human biology, women's health 